Article

\title{
A Comparison of the Role of Voluntary Organizations in Disaster Management
}

\author{
Do-Young Jung ${ }^{1}$ and Kyoo-Man $\mathrm{Ha}^{2, *}$ \\ 1 Dongnam Institute of Radiological \& Medical Sciences, Busan 46033, Korea; jdy0415@hanmail.net \\ 2 Department of Emergency Management, Inje University, Gimhae 50834, Korea \\ * Correspondence: ha1999@inje.ac.kr or ha1999@hotmail.com
}

Citation: Jung, D.-Y.; Ha, K.-M. A Comparison of the Role of Voluntary Organizations in Disaster Management. Sustainability 2021, 13, 1669. https://doi.org/10.3390/ su13041669

\section{Academic Editor:}

Amir Khorram-Manesh

Received: 18 December 2020

Accepted: 31 January 2021

Published: 4 February 2021

Publisher's Note: MDPI stays neutral with regard to jurisdictional claims in published maps and institutional affiliations.

Copyright: (c) 2021 by the authors. Licensee MDPI, Basel, Switzerland. This article is an open access article distributed under the terms and conditions of the Creative Commons Attribution (CC BY) license (https:// creativecommons.org/licenses/by/ $4.0 /)$.

\begin{abstract}
This research aimed to compare different voluntary organizations in disaster management in the United States, Japan, and South Korea. Comparative case studies were used to evaluate the following: the specialized expertise and unsolicited goods and services approach of the United States, the collaborative relations and small-scale approach of Japan, and the additional support and unsystematic coordination approach of community-based organizations in Korea. Three variables were considered: volunteers and their organizations, financial independence, and preferred strategies. The key findings are as follows: each country has tried to enhance the role of its own voluntary organizations in disaster management; the nations studied have similarities and differences in their strategies and actions; and the specific developments in each country have been varied and reflective of its respective culture. This work, as a pioneering study, evaluated three national cases in terms of voluntary organizations in disaster management in the Asia-Pacific region.
\end{abstract}

Keywords: volunteers; comparative case studies; United States; Japan; Korea

\section{Introduction}

Voluntary organizations for disaster management have a more significant impact in the Asia-Pacific today than in the past, considering that the demographics are more rapidly changing and the expectations from volunteers are much more complicated [1]. Recognizing that a single individual or institution is not sufficient to manage the diverse disasters in a region, such as the outbreak of the coronavirus disease 2019 (COVID-19), voluntary organizations for disaster management have become an inevitable part of the system $[2,3]$.

This study chose to focus on the United States, Japan, and South Korea (hereinafter Korea) from among the nations in the Asia-Pacific region. Each of the three nations selected has unique characteristics [4]. The United States is a first world country, highly developed and economically powerful. Tornadoes, hurricanes, floods, snowstorms, and gun violence frequently hit the nation; earthquakes also occur around its western coast. The United States is considered as a frontrunner in the field of volunteer activities. In fact, volunteers account for a large part of its disaster management support. Japan is also strong in this regard, following the United States closely in terms of voluntary organizations involved in disaster management. Several disasters often occur in Japan, including earthquakes that trigger tsunamis, typhoons with resultant floods, heavy snowfall, volcano eruptions, building fires, and school bullying cases. Korea has been steadily working on expanding and modeling its efforts after those of the United States and Japan. Some disasters, such as typhoons with resultant floods, housing fires, and suicides, have strongly affected the nation. Thus, the present research compares these three countries in terms of voluntary organizations for disaster management, in the hope that the data obtained would provide insights on the subject and advance the cause of such organizations.

Fundamentally, all three nations have interacted with one another politically, economically, or culturally. However, few researchers have carried out a rigorous comparison 
among these nations in relation to voluntary organizations in the field of disaster management. In contrast, many studies have examined how voluntary organizations have been oriented toward disaster management in each nation or, at most, in the two nations. By comparing the exposure and experiences of the three countries regarding voluntary organizations for disaster management, this research may draw more unique models or conclusions for the field of disaster management compared with previous studies.

A comparison between the three nations may also yield various significant meanings for this research depending on individual criteria [5]. Such a comparison in relation to cross-national or cross-cultural voluntary organizations for disaster management may contribute to building new theories. A theory is generally defined as a statement that indicates which thing causes what, why, or under what circumstances. Thus, a comparison depends not only on the practitioner but also on the scholarly thrust and can ultimately lead to the formation of appropriate theories. The results of a comparison among three nations could thus contribute to the development of scientific theories [6].

In studies on voluntary organizations for disaster management, the scope of the subject is always an issue [7]. In this situation, a pure case study and the use of limited data cannot directly improve internal validity. Nevertheless, carrying out a comparison helps increase the internal validity of the results. The findings of this work, based on a comprehensive comparison of the three nations, will thus contribute to achieving internal validity.

A general study (or case study) intensively examines a case or some cases based on limited information and resources, whereas a comparison systematically analyzes related cases. In this regard, a comparison between the voluntary organizations for disaster management in three nations may be more promising by utilizing their advantages over their statistics [8]. Although a comparison requires adequate time, energy, and other resources, it may allow delving deeper into the cases compared with a general study $[9,10]$.

A comparison of the voluntary organizations for disaster management in the three nations may ultimately contribute to a greater understanding of the nature of disaster management in relation to voluntary organizations and vice versa [11]. By learning what others are doing regarding voluntary organizations for disaster management, the effectiveness of disaster management and volunteerism may be further strengthened, especially when dealing with disasters of catastrophic scale. At the same time, such knowledge may encourage people to be more practical and open regarding voluntary activities as they become further exposed to the experiences of other countries. In view of these, the present study investigated how the United States, Japan, and Korea have addressed the issue of voluntary organizations for disaster management.

The goal of this study was to compare the role of voluntary organizations for disaster management in the three aforementioned nations toward the ultimate goal of disaster management or transnational disaster management. The goal of disaster management is to mitigate or reduce human losses, economic damages, and psychological impacts, in this case, specifically in the Asia-Pacific region [12]. The present work systematically compares three approaches, namely, the specialized expertise and unsolicited goods/services approach of the United States, the collaborative relations and small-scale approach of Japan, and the additional support and unsystematic coordination approach of community-based organizations (CBOs) of Korea. The comparison considers three variables: volunteers and their organizations, financial independence, and preferred strategies.

Among the many lessons drawn from this comparative study, the key finding is that there is a significant similarity and a significant difference among the three nations. That is, each nation has made efforts to improve the role of voluntary organizations for disaster management in one way or another. However, the specific developments have been very different and meaningful within the context of each nation.

\section{Literature Review}

In general, volunteers are individuals who work in certain fields (in this case, disaster management) without being paid for their services $[13,14]$. In the 21st century, countless 
people have joined or formed voluntary organizations in the Asia-Pacific. Many individuals volunteer for the purpose of sharing their abilities or skills with those affected by disasters, whereas others become volunteers to develop new skills. Some volunteer to give back to their community or to help other communities in order to feel a sense of achievement.

Although volunteers have worked for various disaster spots, their psychological impact from the field has not been equally addressed. Psychological impact includes many symptoms such as post-traumatic stress disorder, anxiety, depression, and even suicide attempts among others. Psychological support for those volunteers has been diverse depending on each nation. Some countries such as the United States have related organizational structure, but open culture is still lacking. Many other countries have not set up evenly related organizational structures $[15,16]$. Therefore, each country needs to substantially provide either formal or informal psychological interventions for exhausted volunteers.

There are many types of volunteers depending on the specific perspective applied. Two types of volunteers are covered in this study: affiliated and unaffiliated volunteers [17]. The former are trained volunteers who belong to recognized voluntary organizations. The latter are self-deployed and usually engage in voluntary work without necessarily having to coordinate their activities with others.

Based on the extensive literature review, the definition of voluntary organizations for disaster management has somewhat varied between nations. For example, Korean CBOs are not included in the category of voluntary organizations for disaster management in the United States, unlike in other nations. In this regard, the United States has adopted restrictive criteria. On the other hand, many developing nations consider $\mathrm{CBO}$ s as voluntary organizations for disaster management. Therefore, their criteria are less restrictive than those of the United States.

In this work, the definition of a voluntary organization for disaster management specifies three requirements [18]. First, the volunteers in the organization should not be paid for their services. Second, an organization should be involved in emergency management. Third, no government should be directly involved in the affairs of the organization, such as government officials serving as committee members.

In the international community, voluntary organizations for disaster management have been variously called nongovernmental organizations (NGOs), not-for-profit organizations (NPOs), civil society organizations (CSOs), and civil society, among others [19]. Although each term has a slightly different meaning within its own context, the terms largely refer to the same organization. The different terms are not discussed extensively in this work. However, the author believes that describing the key aspects of voluntary organizations for disaster management sufficiently touches on each type of group.

A single individual or government may not be able to efficiently manage disasters. Thus, the efforts of all stakeholders are crucial. In this regard, the field of disaster management also needs to maximize the benefits that can be derived from voluntary organizations. The services of voluntary organizations for disaster management have, in fact, been evaluated as more cost-effective than those of other institutions, given their broad range of individual expertise, private resources, task implementation capabilities, and public awareness programs, etc.

During the four phases of the disaster management life cycle, namely, disaster prevention/mitigation, preparedness, response and recovery, voluntary organizations for disaster management have provided unique services and resources. In particular, the role of voluntary organizations for disaster management has been crucial to disaster relief efforts [20]. Being trusted by communities, voluntary organizations for disaster management are often the first to arrive at the disaster area and the last to leave the location.

In the United States, Benjamin Franklin established a volunteer fire department in 1736 as the first voluntary organization for disaster management. Volunteerism has been an American tradition since the colonial days; almost everyone in the nation has served 
as a volunteer in one way or another. However, the activities of voluntary organizations for disaster management have not always been successful. For example, volunteers were not smoothly integrated into the phase of disaster response when hurricane Katrina struck the country in 2005. The staff members of voluntary organizations did not know how to manage their volunteers and the work that had to be done at that time. However, having learned from that experience, when hurricane Sandy hit the east coast of the United States in 2012, volunteers played a role in spreading early warnings and supporting local shelters [21]. Accordingly, several researchers have studied how to improve the role of voluntary organizations in the field of disaster management from various perspectives, such as leadership, participation, and organizational effectiveness. Among them, one research mentioned that the number of volunteers in the United States has steadily decreased in cities and states, compared with twenty years ago. To solve it, All Americans need to clearly recognize the indirect positive effects of volunteering for not only volunteers themselves but also communities [22].

Since about 200 years ago in Japan, informal volunteers have played their own roles in managing multiple disasters such as fires, typhoons accompanied by flood, earthquakes, and others [23]. Informal volunteers do no help disaster victims via formal organizations but directly give their help to disaster spots. Their activities have been evaluated as very visible in disaster spots. Japan's informal volunteers are an example of localization on volunteering infrastructure. However, the Western concept of voluntary organizations has been relatively new one in the nation. Nonetheless, many researchers have studied how such organizations have contributed to mitigating the impact of natural disasters (also known as natural hazards), and subsequent related studies have significantly increased. About 1.3 million volunteers came to Kobe in 1995 to help in the recovery efforts after the occurrence of an earthquake. In view of the positive Kobe experience, Japan passed the Special Nonprofit Activities Law (also known as the NPO Law) in 1998. Since then, cooperation between voluntary organizations for disaster management and the government has increased, aided by the relaxation of requirements for NPOs and their growth [24]. After the Tohoku earthquake in 2011, voluntary organizations were highly praised for their role in disaster management because of the professionalism they showed [25]. During the subsequent Fukushima Daiichi Nuclear Power Plant disaster, many researchers noted that volunteers played various crucial roles, such as cooking and serving food, shoveling ditches for water drainage, searching for valuables in housing facilities, and providing physical assistance and emotional support to the victims [26]. Lately, the increasing number of researchers has seriously discussed how to respond to the outbreak of COVID-19 in Japan. To the point, one study examined how to deal with double threats such as COVID-19 outbreak and flood occurrence. As a finding, the study recommended the importance of further coordination among various organizations such as health facilities, water control institutions, humanitarian organizations, and voluntary organizations [27].

Similarly to Japan, the history of voluntary organizations for disaster management in Korea is not that long. Although Korea has traditionally used cooperative activities in the community, such as Gye (a sort of fraternity) and Dure (a type of mutual aid farming team), voluntary organizations for disaster management started their activities in the nation only at the end of the 20th century. Throughout a series of natural disasters (e.g., typhoon Maemi in 2003 and a 5.4 magnitude earthquake in Pohang in 2017) and man-made emergencies (e.g., the Daegu subway fires in 2003, the sinking of the ferry MV Sewol around Jindo in 2014, and the Miryang fire in 2018), an increasing number of volunteers have contributed to the goal of disaster management $[28,29]$. Accordingly, more and more researchers have examined the role of voluntary organizations for disaster management not only in terms of theoretical applications but also case studies [30]. Among many of these, one recent study assumed that volunteering plays many roles in managing multiple contingencies to include mega sports games and other emergencies. In doing so, the research has empirically proven determinants of volunteer satisfaction such as the extent of volunteer involvement, 
voluntary activities, and the fulfillment of volunteers' needs. The study emphasized that volunteers' satisfaction will positively influence their intention of future volunteering [31].

Internationally recognized studies on voluntary organizations for disaster management have been carried out in the United States, Japan, and Korea. Some comparative studies have also been performed, such as between the United States and Japan, between the United States and Korea, and between Japan and Korea [32]. However, few works have attempted to compare voluntary organizations for disaster management, particularly among these three nations. In contrast to many previous studies, the present research rigorously analyzed voluntary organizations for disaster management in the three nations from an international perspective. The criteria used, widely recognized in the international community, include several transnational disaster management principles, such as comprehensive emergency management, networking among various stakeholders, and the whole community approach. Hence, this work has potential value as a pioneering research.

\section{Research Design}

Comparative case studies examine two or more cases toward formulating generalized theories, whereas a case study analyzes a single case [33]. In the present work, a comparative case study is used to compare voluntary organizations for disaster management between three nations (i.e., the United States, Japan, and Korea), from which generalized knowledge is drawn. Under this methodology, the different conditions or contexts in the three nations are compared.

Qualitative data are frequently used in comparative case studies. The present work obtained such data by using Internet search engines, such as ScienceDirect, EBSCOhost, Google Scholar, and Yahoo. Among the keywords used were "volunteers," "disaster management," "voluntary organizations for disaster management," "the United States," "Japan," and "Korea."

For a systematic comparison, the same type of qualitative data (or comparison resources) is generally preferred. In this study, however, various types of qualitative data were identified and then analyzed, including research reports, books, government documents, and websites. Considering that each country has its own level of research on voluntary organizations, the availability of a specific resource type differs. Regarding national voluntary organization network(s), many U.S. government documents are generally available [34]. Both research reports and Internet information are available in Japanese networks [35], whereas Internet information is abundant in Korean networks [36].

There are different ways of doing comparative case studies depending on the specific focus [37]. In this study, the common characteristics of voluntary organizations for disaster management in the three nations were first classified based on the rationale of comparison, with the goal of drawing general statements on the relationships among these voluntary organizations.

Three characteristics common to the three nations were taken as comparative variables (Figure 1), based on the extensive literature review. Each characteristic has its own justification for inclusion. The first variable, volunteers and their organizations, refers to major players in the field [38], which are the main subjects of this study. The second variable, financial independence, means that voluntary organizations have enough income for their own expenses, in particular, without depending on others. Financial independence has been somewhat differently defined, depending on a major ideology, voluntarism, and the relationship between government and private industry in each nation. Financial independence is always important in NPO activities because sufficient funding is necessary for survival, task implementation, and volunteer support, especially since voluntary organizations often have no other sources of income [39]. The third variable, preferred strategies, refers to the ways in which the affairs of voluntary organizations for disaster management are technically managed [40]. While the ends of disaster management are achieved by the means, preferred strategies should be customized on the basis of governance mechanism in each nation. These strategies are influenced by many factors, such as the tasks involved 
and their interdependence on each other. Overall, these three variables are essential to voluntary organizations for disaster management.

\section{The role of voluntary organizations for disaster management in the Asia Pacific field \\ - comparative case studies -}

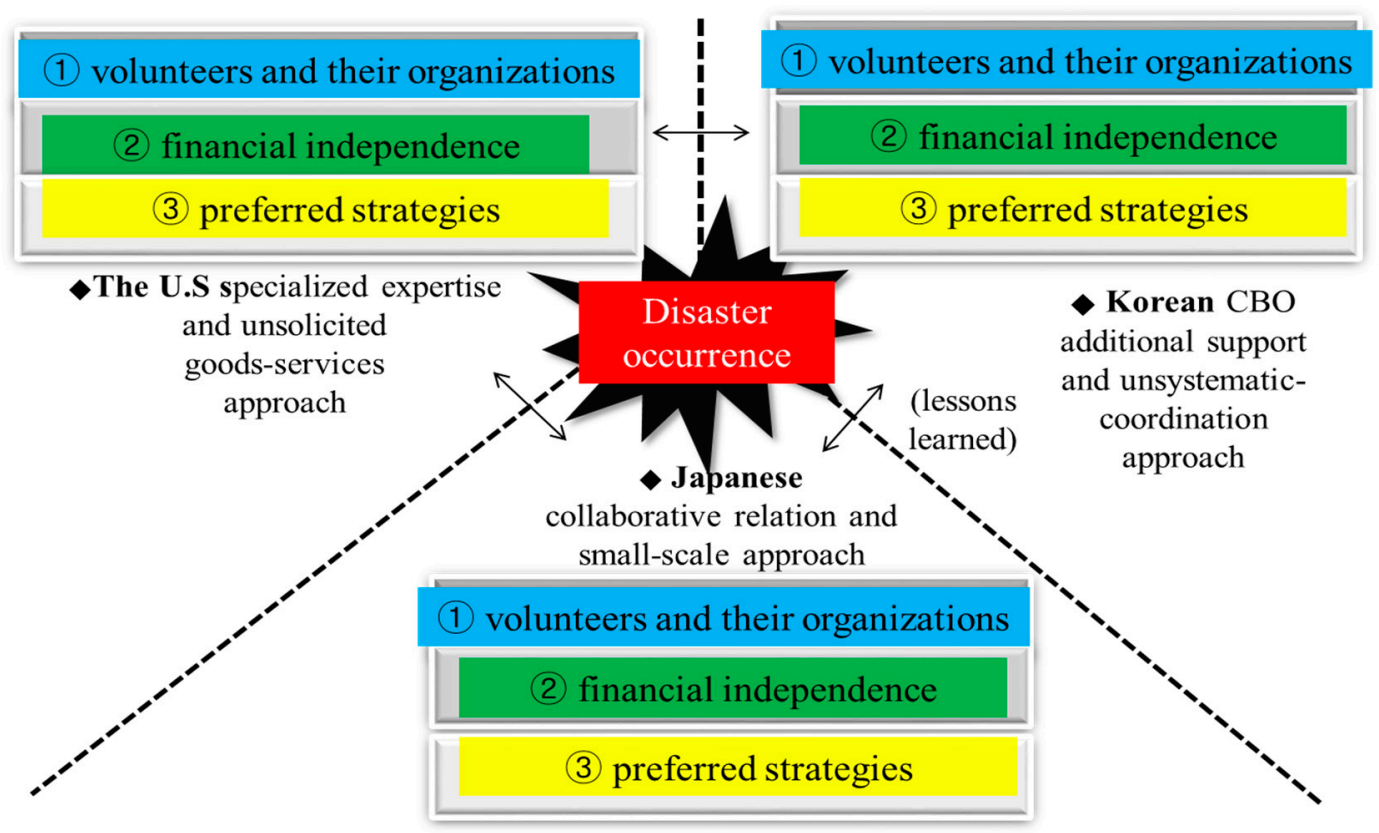

Figure 1. Analytical framework.

In examining the characteristics of the three nations, each approach was given an appropriate label. After the review of the qualitative data, a temporary label was first assigned to each nation. These labels were then modified or improved as the interpreted qualitative data were recorded. Thus, without the extensive literature review, the logical assignment of those labels would not have been possible. The three approaches involve both the positive and the negative aspects of voluntary organizations for disaster management. This study comprehensively considers the similarities and differences among voluntary organizations for disaster management in the three nations [41], while also drawing the lessons learned from one another.

The methodology of the comparative case studies used here entails designing a similar system among the three nations, considering the effort to assign an appropriate label for each national voluntary organization for disaster management. Moreover, the methodology designs completely different contents under each comparative variable or label. Hence, the methodology designs a mixed system for the three nations.

\section{U.S. Specialized Expertise and Unsolicited Goods/Services Approach 4.1. Volunteers and Their Organizations}

American volunteers, both affiliated and unaffiliated, provide material resources and expertise to the field of disaster management [42]. On some occasions, unaffiliated volunteers may have a negative impact on disaster management activities, such as when they provide goods and services that are not necessarily the priority needs of the affected communities [43]. However, affiliated and unaffiliated volunteers generally play important roles in supporting disaster survivors, such as by providing emotional care, mass care, shelter (even for pets), cleanup assistance, and transportation.

The registration of a voluntary organization in a state does not rely on a fixed method and is dependent on the regulations of each state. In general, a voluntary organization 
for disaster management registers in its preferred state, from which it then receives an employer identification number. The voluntary organization then works in the field of emergency management, primarily by providing specialized expertise.

To minimize the extent of overlapping expertise or activities among major voluntary organizations for disaster management at the national level, the United States set up the National Voluntary Organizations Active in Disaster (NVOAD) in 1970 [44]. The NVOAD temporarily ceased its activities after the 9/11 terrorist attack in New York. However, its role and involvement in disaster management have expanded considerably following the huge impact of hurricane Katrina in 2005 [45]. At the local level, the United States turns to the VOAD, which, similarly to the NVOAD, is a coalition of voluntary organizations for disaster management.

\subsection{Financial Independence}

Voluntary organizations for disaster management receive minimal amounts of funding from emergency operations [46]. Although membership fees raise a significant amount for voluntary organizations, the bulk of their funding still comes from donations. Having sufficient funding allows many voluntary organizations for disaster management some flexibility in the disposition of their finances.

Internal Revenue Service regulations grant tax exemptions to voluntary organizations for disaster management and their donors. In general, these organizations and donors do not need to pay federal or state income taxes as long as they are not involved in politics or for-profit activities [47]. Furthermore, voluntary organizations for disaster management may legally accept grants or funds from foreign countries as long as the money does not come from banned sources, such as terrorist organizations.

Although volunteer labor is largely free, running volunteer programs entails considerable expenses. Thus, voluntary organizations for disaster management in the United States strongly advocate fund-raising volunteer programs. In many cases, the board treasurer manages the finances of the group; however, some larger organizations can afford to hire an accountant or an outside firm to handle their finances.

\subsection{Preferred Strategies}

The Robert T. Stafford Act placed the various activities of voluntary organizations for disaster management under the National Response Framework (NRF) [48]. Despite being managed from the macro-perspective of the NRF, many voluntary organizations for disaster management have tried to provide specialized expertise, such as disaster relief under the U.S. Red Cross, disaster training and exercises under the International Association of Emergency Managers, and others.

Many voluntary organizations for disaster management prefer donations in cash or in kind because donations of goods may entail logistical challenges. However, many such organizations also request different items at different times. For example, during the recent flooding in the state of Louisiana, many voluntary organizations for disaster management requested donations of specific supplies, such as cleaning products and clothing. In some cases, unsolicited donations, such as chemicals, household goods, and building materials, continuously arrive at disaster-stricken areas, sometimes aggravating the situation instead of easing it.

To address the issue of unsolicited goods, the National Donations Steering Committee created the Donations Coordination Team in 1993 to implement the National Donations Management Strategy. The United States also uses the National Donations Management Network and the Multi-Agency Warehouse to facilitate the acceptance, distribution, transport, and warehousing of unsolicited donations [49]. 


\section{Japanese Collaborative Relations and Small-Scale Approach \\ 5.1. Volunteers and Their Organizations}

In Japan, the number of volunteers at the national level has increased in recent years. Firefighting, flood protection, and elementary school district (known as Bokomi) volunteers are the three sectors or teams that often sacrifice their time, money, and efforts to deal with local fires, floods, and typhoons [50].

The majority of voluntary organizations for disaster management have a small number of registered volunteers, with only about $11 \%$ of these groups having more than 50 members. The biggest category of voluntary organizations for disaster management in Japan represents only one third of that in the United States. Similarly, the number of staff in such organizations is relatively small, with about $50 \%$ of the groups having less than 20 staff [51,52].

Japan has attempted to set up nationwide networks for voluntary organizations for disaster management, including the National Earthquake Disaster Network in 1997 and the Disaster Relief Network (J-Net) in 2000 [53]. However, those networks have not been evaluated as successes, considering that many have operated their activities within a limited region, with more than $80 \%$ engaged in activities within only one city or prefecture $[54,55]$. Notwithstanding, the activities of nationwide networks have somewhat increased at present, due the occurrence of catastrophes, the development of information and communication technology, and an increase in public awareness [56]. These networks include the Japan Women's Network for Disaster Risk Reduction and Japan's Free Disaster WiFi service, among others.

\subsection{Financial Independence}

A voluntary organization for disaster management that registers its name and related information with the Japanese government, thus becoming a member of an incorporated association, receives tax breaks and legal protection from the government. In contrast, a voluntary organization for disaster management that does not register with the government becomes a member of an unincorporated association and may enjoy free activities [57].

In general, because of government regulations and indirect restrictions, the majority of voluntary organizations for disaster management have become members of incorporated associations; that is, they have officially registered with the government. Thus, they enjoy some tax breaks but not free activities. Tax treatments have also been given to donors or donations to voluntary organizations for disaster management since June 2011.

Most voluntary organizations for disaster management have relatively small budgets. Their annual budgets of about $54 \%$ are less than USD 123,000, which is a relatively small amount [58]. Therefore, they are conscious about providing low-cost products and services to ensure that they remain within their budgets.

\subsection{Preferred Strategies}

Under the Disaster Countermeasures Basic Act (DCBA), the Japanese government has tried to provide a healthy environment for volunteer activities or voluntary organizations for disaster management [59]. A good example is the Local Council for Countermeasures Regarding Displaced Residents around the Yurakucho and Tokyo stations. However, the government has also been considered to have often weakened the role of voluntary organizations for disaster management through its regulatory restrictions.

Nevertheless, the relationship between voluntary organizations for disaster management and the government has been widely regarded as quite cooperative. During the phase of disaster response or recovery, many volunteers or voluntary organizations for disaster management have willingly complied with government orders and have successfully participated in mitigating the impacts of disaster.

Small-scale voluntary organizations for disaster management have also begun expanding their activities to include the international community. With globalization, foreign aid and international development and cooperation have become possible and progressive. 
In fact, about 217 voluntary organizations for disaster management are affiliated with the United Nations Economic and Social Council as of 2012 [60].

\section{Korean CBO Additional Support and Unsystematic Coordination Approach 6.1. Volunteers and Their Organizations}

Voluntary organizations for disaster management began to play a significant role in Korea following the oil leakage around its west coast in 2007. The MT Hebei Spirit owned by Samsung Heavy Industries had caused a huge oil spill, considered the worst oil leakage in Korea. Many people came to the disaster area to clean up the oil even during the period of the presidential election. The majority of volunteers used towels to clean the leaked oil on the rocks or beaches [61]. In 2011, having watched the Fukushima nuclear disaster on television or the Internet, Koreans donated USD 56 million to the disaster-stricken area. This gesture was quite remarkable and may even be considered a "cultural revolution" because of the tragic historical experience of Koreans with Japan, specifically the killing of 6000-10,000 Koreans with bamboo spears during an earthquake in Kanto, Japan, in $1923[62,63]$.

Many Korean volunteers belong not to voluntary organizations for disaster management but to CBOs. That is, they have participated in voluntary works carried out under CBOs, such as Youth Club, Married Women Group, and Senior Citizen Group. The original goal of CBOs is not confined to disaster management but instead covers all activities in a community. Thus, CBOs have directly or indirectly supported volunteer activities in Korea.

The Korea Disaster Safety Network (KDSN) coordinates the various activities of voluntary organizations for disaster management in the nation. This group includes not only the members of voluntary organizations for disaster management but also the Ministry of the Interior and Safety (MOIS) under the 19th president. However, although the KDSN has provided short-term training and exercise programs for countless volunteers, its original goal has not been achieved [64], that is, it has not prevented overlapping between the specific service of each voluntary organization for disaster management.

\subsection{Financial Independence}

The survival of voluntary organizations for disaster management in Korea is generally decided within the first year of their establishment [65]. That is, a voluntary organization that becomes financially independent by the end of its first fiscal year has a high survival rate in the field. Hence, many organizations seek to achieve financial independence at the beginning of their operations.

The MOIS provides substantial assistance to support the financial independence of voluntary organizations for disaster management, including grants and other financial aids, funding for research projects, postage reduction, and other administrative benefits [66]. However, although many such organizations have enjoyed the mailing cost reduction and administrative benefits, they have to get through tough competition to obtain grants, financial aids, and research projects.

Many voluntary organizations for disaster management have limited budgets (e.g., an estimated USD 200,000 yearly). Thus, they also rely on membership fees and donations, which are not sufficient for them to achieve financial independence. To help address this concern, some organizations issue an emergency manager certification for a fee to those who complete the related training and exercise.

\subsection{Preferred Strategies}

Under the Basic Act of Emergency and Safety Management, voluntary organizations for disaster management have tried to supplement the activities of the government [67]. The Korea Business Continuity Planning Association (KBCPA) was initiated to provide business continuity planning to the field, even when the government did not consider this to be necessary. In addition, with the support of the government, the Association of Slope Disaster Mitigation has implemented diverse alternatives against mountain landslides. 
Under the Korean environment, it has not been easy for voluntary organizations for disaster management to carry out their activities without financial assistance and government support [68]. Thus, many voluntary organizations for disaster management have made efforts to obtain government assistance through formal and informal channels. This often results in complicated relations, tainted by dirty politics, between institutions.

Voluntary organizations for disaster management have frequently applied strategies from successful cases, such as the whole community approach and integrated emergency management system. However, the application of these strategies has been somewhat manipulated or unsystematic. For instance, the KBCPA intentionally maintained that business continuity planning is not equal to the continuity of operation but to disaster management to expand the scope of its activity.

\section{Major Implications}

From the perspective that nobody invests in free goods and voluntary activities, some people might regard investment in voluntary organizations for disaster management as a form of cheating. However, voluntary efforts are part of a process that connects nonprofit with mission-related goods and services, as in the case of marketing or financial development $[69,70]$. Thus, investing in voluntary organizations for disaster management makes sense.

Based on the concept of feasible investment, three nations have willingly facilitated appropriate investments in voluntary organizations for disaster management, including the distribution of emergency products, the efficient utilization of funds, the investment of time, or changes in behavior. Concrete examples include the Bank of America Charitable Foundation, Hands on Tokyo, and Seoul International Women's Association, in order. At the same time, by participating in the process of achieving a scientific vision for voluntary organizations for disaster management, major stakeholders have supported the core of disaster management under its own culture.

Each national case has various aspects. In particular, the United States has a long history in developing and then managing formal voluntary organizations for effective disaster management. Although Japan and Korea have a short history in terms of the Western concept of voluntary organizations, the activities of their informal volunteers have historically been quite effective in disaster spots. At any rate, each national case may be comparatively or satisfactorily labeled by referring to a major positive aspect and a major negative aspect. Thus, the following labels were given: the U.S. specialized expertise and unsolicited goods/services approach, the Japanese collaborative relations and small-scale approach, and the Korean CBO additional support and unsystematic coordination approach.

Similarly, it has not been easy to draw a single similarity and a single difference among the voluntary organizations for disaster management from the three nations, mainly because several positive or negative aspects have been outlined in each case. Nonetheless, among the three, a major similarity is that each nation has made efforts to improve the role of voluntary organizations for disaster management, whereas a major difference is that the specific development of each nation has been different and meaningful within its own context [71].

In view of the above labels, similarity, difference, and other factors, each nation may learn lessons from one another, as shown in the summary in Table 1. Despite its long history of voluntary organizations for disaster management, the United States is not necessarily always superior to Japan and Korea. Rather, the United States may equally learn from the other two nations under its own environment. The same principle applies to both Japan and Korea. Hence, by studying the two other cases, each nation can avoid committing the same mistakes in its own field of disaster management [72]. From Japan, for example, the United States may learn about the role of the government and the international activities of voluntary organizations. From Korea, the United States may learn about the integration of CBOs and mass media support into disaster response/recovery. Japan in turn may learn 
about specialized expertise and DCBA upgrade from the United States and about informal communication and national networks from Korea. Finally, Korea may learn about future concerns and the NVOAD from the case of the United States and about international activities and financial independence from the experience of Japan.

Table 1. Lessons for the United States, Japan, and Korea.

\begin{tabular}{|c|c|c|c|}
\hline Nation/Approach & $\begin{array}{l}\text { (1) United States/Specialized } \\
\text { Expertise and Unsolicited } \\
\text { Goods/Services Approach }\end{array}$ & $\begin{array}{c}\text { (2) Japan/Collaborative } \\
\text { Relations and Small-Scale } \\
\text { Approach }\end{array}$ & $\begin{array}{l}\text { (3) Korea/CBO Additional } \\
\text { Support and Unsystematic } \\
\text { Coordination Approach }\end{array}$ \\
\hline United States & - Not applicable. & $\begin{array}{l}\text { - Similarly to Japan, the U.S. } \\
\text { government should strengthen its } \\
\text { collaboration with voluntary } \\
\text { organizations for disaster } \\
\text { management by emphasizing its } \\
\text { proactive support. } \\
\text { - Local voluntary organizations in } \\
\text { the United States may consider } \\
\text { further expanding their activities } \\
\text { in the international community. }\end{array}$ & $\begin{array}{l}\text { - Following Korea, the United } \\
\text { States may further incorporate } \\
\text { the role of CBOs into disaster } \\
\text { management. } \\
\text { - The United States may increase } \\
\text { its broadcast of the disaster } \\
\text { response or recovery phase on } \\
\text { television, the Internet, or other } \\
\text { platforms. }\end{array}$ \\
\hline Japan & $\begin{array}{l}\text { - Similarly to the United States, } \\
\text { Japan should encourage each } \\
\text { voluntary organization for } \\
\text { disaster management to develop } \\
\text { more specialized expertise. } \\
\text { - Japan may upgrade its DCBA to } \\
\text { the level of the U.S. NRF. }\end{array}$ & - Not applicable. & $\begin{array}{l}\text { - Similarly to Korea, Japan may } \\
\text { expand its small-scale } \\
\text { management by relying on } \\
\text { informal communication } \\
\text { channels among voluntary } \\
\text { organizations for disaster } \\
\text { management. } \\
\text { - Japan should more } \\
\text { substantially systematize its } \\
\text { national networks. }\end{array}$ \\
\hline Korea & $\begin{array}{l}\text { - Korea must consider the U.S. } \\
\text { approach of specialized expertise } \\
\text { and unsolicited goods/services to } \\
\text { be among its concerns in the field. } \\
\text { - KDSN needs to decrease the } \\
\text { extent of overlapping activities } \\
\text { among voluntary organizations } \\
\text { following the U.S. NVOAD. }\end{array}$ & $\begin{array}{l}\text { - Korea should try to } \\
\text { internationalize the activities of } \\
\text { its voluntary organizations for } \\
\text { disaster management, as in the } \\
\text { case of Japan. } \\
\text { - Korean voluntary organizations } \\
\text { for disaster management may } \\
\text { also consider providing low-cost } \\
\text { services in the field to achieve } \\
\text { financial independence, similarly } \\
\text { to Japan. }\end{array}$ & - Not applicable. \\
\hline
\end{tabular}

To further promote or implement the above lessons, the field of disaster management in each nation should allow all people to share a common goal in the region [73]. A good example is the phase of emergency response to COVID-19 outbreak in the world. Not all residents are impacted when a disaster hits an area. However, when even those who are not impacted by the disaster feel a certain extent of risk, then they would be willing to apply the lessons learned.

In sharing a common goal in a community, the national field of disaster management has to continually plan related programs or volunteer involvement activities. Examples in three countries include Montgomery County Volunteer Center, Japan Platform, and Korea International Volunteer Organization. Moreover, each national field must evaluate the role of voluntary organizations for disaster management over a long period. Thus, the related planning and evaluation must be carried out in terms of management sustainability $[74,75]$.

During all four phases of the disaster management life cycle, voluntary organizations for disaster management need to communicate the risks with not only their volunteers but also governments, industries, mass media, and local communities [76,77]. Examples of disaster communication failure in the three nations include hurricane Katrina in 2004, 
Fukushima nuclear leakage in 2011, and the sinking of ferry Sewol in 2014. In this context, risk communication is necessary toward implementing the lessons learned, whether during a catastrophe or during normal times. Thus, each nation should try to correct its own problems by freely communicating with one another in a timely manner.

All three nations could use advanced information and communication technology more systematically than they are currently doing. Digital volunteerism can not only help disseminate disaster information but also produce new information [78-80]. Therefore, information and communication technology, or digital volunteerism, may be used as an efficient tool to implement the lessons learned.

As managerial insight, the results of this paper may help multiple stakeholders to deal with not only natural hazards but also man-made emergencies in complicated environment. To elaborate, this paper will directly facilitate both managers of voluntary organizations and volunteers to make a specific decision on their urgent business in three nations [81]. In addition, this study will help other stakeholders such as public officials, businessmen, local residents, and other emergency managers to identify the appropriate options or opportunities around voluntary organizations.

A limitation of this paper has been related to one issue in methodology. While comparing three nations, an ideal is that the same type of qualitative information and data will be systematically compared and contrasted regarding a specific subject. However, because each country has a substantially developed own research level, research culture, and other environments around voluntary organizations, it has been difficult for this study to search for and then utilize the same type of comparison resources for the subject. Nonetheless, this limitation has not been an issue of research contents but a matter of resource type.

\section{Conclusions}

This study carried out a systematic comparison of the role of voluntary organizations for disaster management in three nations. Three models were determined and then appropriately labeled, namely, the U.S. specialized expertise and unsolicited goods/services approach, the Japanese collaborative relations and small-scale approach, and the Korean $\mathrm{CBO}$ additional support and unsystematic coordination approach. The lessons learned from the three nations were also identified, which may ultimately contribute to achieving the goals of disaster management, such as mitigating human losses, economic damages, and psychological impacts in the Asia-Pacific region.

Many negative and positive aspects of voluntary organizations for disaster management, as well as the lessons learned from the national cases, were discussed in this work. However, the key finding of the comparative case study is that there is a major similarity and a major difference among the disaster management efforts among the three nations. That is, although the three nations have similarly tried to address the role of voluntary organizations for disaster management in the region, each process has been varied and meaningful within the specific national environment. All stakeholders in voluntary organizations for disaster management must reflect this finding toward the implementation of the lessons learned.

The strength of this research lies in the pioneering study of not only one or two cases but of three national cases in terms of voluntary organizations for disaster management in the Asia-Pacific region. Many researchers have explored the case of the United States, Japan, or Korea, and some have attempted to carry out comparisons between at most two cases at a time. A comparative perspective considering three nations is academically rare and could thus provide new alternatives in the study of voluntary organizations for disaster management in the region.

Future research may expand the results of this work to other national contexts. The three variables considered, namely, volunteers and their organizations, financial independence, and preferred strategies, may also be extended to include other factors. Moreover, when reflecting that a limitation of this research has been the difficulties of finding the same 
type of comparison resources, appropriate researchers may try to examine how to newly solve this methodological challenge. Given the present globalization, the comparative perspective has been increasingly applied in research. In this regard, other works may compare the disaster management efforts of specific nations with those of the United States, Japan, Korea, and other countries toward the ultimate goal of transnational disaster management.

Author Contributions: Conceptualization, D.-Y.J.; writing-original draft preparation, D.-Y.J.; writing-review and editing, K.-M.H. All authors have read and agreed to the published version of the manuscript.

Funding: Funding information is not applicable to this research.

Institutional Review Board Statement: Not applicable.

Informed Consent Statement: Not applicable.

Data Availability Statement: Not applicable.

Conflicts of Interest: The authors declare no conflict of interest.

\section{References}

1. Lewis, D.; Kanji, N. Non-Governmental Organizations and Development, 1st ed.; Routledge: New York, NY, USA, 2009 ; pp. 121-141.

2. Darley, S. Transforming the world and themselves: The learning experiences of volunteers being trained within health and social care charities in England. Volunt. Sect. Rev. 2016, 7, 219-228. [CrossRef]

3. During These Uncertain Times, How Can We Help? Available online: https://www.volunteermatch.org/covid19?gclid= CjwKCAjw5Ij2BRBdEiwA0Frc9VzHo6417AAt6NyU0NBMnpuZySQp9uiM5TvcAKGn0U7O7KDwSXHc4BoCJr0QAvD_BwE (accessed on 24 December 2020).

4. Penuel, K.B.; Statler, M. Encyclopedia of Disaster Relief, 1st ed.; SAGE Publications: London, UK, 2010; pp. 807-819.

5. Waldo, D. Comparative public administration: Prologue, performance, problems, and promise. In Comparative Public Administration: The Essential Readings, 1st ed.; Otenyo, E.E., Lind, H.S., Eds.; Elsevier: New York, NY, USA, 2006; pp. 129-170.

6. Marume, S.B.M.; Jubenkanda, R.R.; Namusi, C.W. Comparative public administration. Int. J. Sci. Res. 2016, 5, $1025-1031$.

7. Boeije, H. A purposeful approach to the constant comparative method in the analysis of qualitative interviews. Qual. Quan. 2002, 36, 391-409. [CrossRef]

8. Collier, D. The comparative method. In Political Science the State of the Discipline II, 1st ed.; Finifter, A.W., Ed.; American Political Science Association: Washington, DC, USA, 1993; pp. 105-119.

9. Rohner, R.P. Advantages of the comparative method of anthropology. Cross-Cult. Res. 1977, 12, 117-144. [CrossRef]

10. Sanford, G.M.; Lutterschmidt, W.I.; Hutchison, V.H. The comparative method revisited. BioScience 2002, 52, 830-836. [CrossRef]

11. Rational for the Study of Comparative Education. Available online: http://camponotes.blogspot.kr/2013/01/rationale-forstudy-of-comparative.html (accessed on 27 November 2020).

12. The Disaster Management Cycle. Available online: http://www.gdrc.org/uem/disasters/1-dm_cycle.html (accessed on 13 October 2020).

13. Roth, S. Aid work as edgework-Voluntary risk-taking and security in humanitarian assistance, development and human rights work. J. Risk Res. 2015, 18, 139-155. [CrossRef]

14. Volunteering in the United States. 2015. Available online: http://www.bls.gov/news.release/volun.nr0.htm (accessed on 7 October 2020).

15. Macpherson, R.I.S.; Burkle, F.M. Humanitarian aid workers: The forgotten first responders. Prehospital Disaster Med. 2021, 36, 111-114. [CrossRef]

16. Milligan-Saville, J.; Choi, I.; Deady, M.; Scott, P.; Tan, L.; Calvo, R.A.; Bryant, R.A.; Glozier, N.; Harvey, S.B. The impact of trauma exposure on the development of PTSD and psychological distress in a volunteer fire service. Psychiatry Res. 2018, 270, 1110-1115. [CrossRef]

17. Pre-Planning in the World of Volunteer Management. Available online: http:/ / patimes.org/pre-planning-world-volunteermanagement/ (accessed on 6 November 2020).

18. What is the Voluntary Sector? Available online: https://reachvolunteering.org.uk/guide/what-voluntary-sector (accessed on 19 January 2021).

19. How to Get Your First Job in the Charity Sector. Available online: https://blogs.lse.ac.uk/careers/2017/06/19/how-to-get-yourfirst-job-in-the-charity-sector/ (accessed on 24 January 2021).

20. Non-Government Aid Crucial to Disaster Relief Operations. Available online: http://www.nationaldefensemagazine.org/ articles /2008/6/1/2008june-nongovernment-aid-crucial-to-disaster-relief-operations (accessed on 6 November 2020).

21. Johnson, T.R. IIGR Working Paper Series: Disaster Volunteerism, 1st ed.; International Institute of Global Resilience: Washington, DC, USA, 2014; pp. 20-27. 
22. School of Public Policy, University of Maryland. Why Are America's Volunteers, 1st ed.; Do Good Institute: College Park, MD, USA, 2018; pp. 1-22.

23. UNV. Global Trends in Volunteering Infrastructure, 1st ed.; UNV Programme: Bangkok, Thailand, $2018 ;$ pp. 10-15.

24. Pekkanen, R. Japan's new politics: The case of the NPO law. J. Jpn. Stud. 2000, 26, 111-148. [CrossRef]

25. Atsumi, T. Against the drive for institutionalization: Two decades of disaster volunteers in Japan. In Hazards, Risks and Disasters in Society, 1st ed.; Collins, A., Samantha, J., Manyena, B., Walsh, S., Shroder, J.F., Jr., Eds.; Elsevier: Tokyo, Japan, 2015; pp. 19-32.

26. McMorran, C. From volunteers to volunteers: Shifting priorities in post-disaster Japan. Jpn. Forum. 2017, 29, 558-582. [CrossRef]

27. Ishiwatari, M.; Koike, T.; Hiroki, K.; Toda, T.; Katsube, T. Managing disasters amid COVID-19 pandemic: Approaches of response to flood disasters. Prog. Disaster Sci. 2020, 6, 100096. [CrossRef]

28. Bae, J.; Lam, E.T.C.; Lee, H.-G. Motivation of South Korean volunteers in international sports: A confirmatory factor analysis. Int. J. Volunt. Adm. 2016, 32, 1-55.

29. Volunteers Find Scenes of Hope Despair at S. Korea Ferry Site. Available online: https://www.csmonitor.com/World/AsiaPacific/2014/0422/Volunteers-find-scenes-of-hope-despair-at-S.-Korea-ferry-site-video (accessed on 25 December 2020).

30. Kim, I.-C.; Hwang, C.-S. Defining the Non-profit Sector: South Korea, 1st ed.; The John Hopkins Center for Civil Society Studies: Baltimore, MD, USA, 2002; pp. 1-21.

31. Kim, D.; Park, C.; Kim, H.; Kim, J. Determinants and outcomes of volunteer satisfaction. Sustainability 2019, 11, 1859. [CrossRef]

32. Greer, A. Earthquake preparedness and response: Comparison of the United States and Japan. Leadersh. Manag. Eng. 2012, 12, 111-125. [CrossRef]

33. Goodrick, D. Comparative Case Studies, 1st ed.; UNICEF Office of Research: Florence, Italy, 2014; pp. 1-11.

34. National VOAD Committee Manual. Available online: https://3hb3e83li75iliikjx1wkj2o-wpengine.netdna-ssl.com/wp-content/ uploads/NVOAD-Ad-Hoc-Committee-Manual-Apr-2020-FINAL.pdf (accessed on 13 October 2020).

35. Lee, J.; Fraser, T. How do natural hazards affect participation in voluntary association? The social impacts of disasters in Japanese society. Int. J. Disaster Risk Reduct. 2019, 34, 108-115. [CrossRef]

36. SafeNet Forum Is. Available online: http:// safenetforum.or.kr/eng $/ \mathrm{main} / \mathrm{main} . \mathrm{php}$ ?categoryid=02\&menuid=01\&groupid=00 (accessed on 24 September 2020).

37. Rathod, P.B. Comparative Public Administration, 1st ed.; ABD Publishers: New Delhi, India, 2007; pp. 112-132.

38. Bruce, D.; Jordan, P.; Halseth, G. The Role of Voluntary Organizations in Rural Canada: Impacts of Changing Availability of Operational and Program Funding, 1st ed.; Canadian Rural Restructuring Foundation: Nelson, BC, Canada, 1999; pp. 25-41.

39. The Path to Financial Independence in Detail. Available online: https://www.thesimpledollar.com/financial-wellness/the-pathto-financial-independence-in-detail/ (accessed on 19 November 2020).

40. Wilson, D.C.; Butler, R.J. Voluntary organizations in action; strategy in the voluntary sector. J. Manag. Stud. 1986, $23,519-542$. [CrossRef]

41. Lee, Y.-J.; Wilkins, V.M. More similarities or more differences? Comparing public and nonprofit managers' job motivations. Public Adm. Rev. 2011, 71, 45-56. [CrossRef]

42. O'Connell, B. What voluntary activity can and cannot do for America. Public Adm. Rev. 1989, 49, 486-491. [CrossRef]

43. Emergency Management Institute (EMI). Developing and Managing Volunteers, 1st ed.; EMI: Emmitsburg, MD, USA, 2013 ; pp. $23-45$.

44. Long Term Recovery Guide. Available online: http://www.cadresv.org/wp-content/uploads/2012/10/long_term_recovery_ guide_-_final_20121.pdf (accessed on 19 November 2020).

45. Haddow, G.D.; Bullock, J.A.; Coppola, D.P. Introduction to Emergency Management, 1st ed.; Elsevier Inc.: Cambridge, MA, USA, 2017; pp. 33-78.

46. Loehman, E.; Loomis, J. In-stream flow as a public good: Possibilities for economic organization and voluntary local provision. Rev. Agric. Econ. 2008, 30, 445-456. [CrossRef]

47. Voluntary Action Network India (VANI). Enabling Environment for Voluntary Organizations: A Global Campaign, 1st ed.; VANI: New Delhi, India, 2013; pp. 10-47.

48. Federal Emergency Management Agency (FEMA). Robert T. Stafford Disaster Relief and Emergency Assistance Act, as Amended, and Related Authorities, 1st ed.; FEMA: Washington, DC, USA, 2007; pp. 22-29.

49. EMI. The Role of Voluntary Organizations in Emergency Management, 1st ed.; EMI: Emmitsburg, MD, USA, 2015 ; pp. $2-15$.

50. National Report of Japan Disaster Reduction for the World Conference on Disaster Reduction (Kobe-Hyogo, Japan 18-22 January 2005). Available online: http:/ / www.unisdr.org/2005/mdgs-drr/national-reports/Japan-report.pdf (accessed on 19 November 2020).

51. Bothwell, R.O. The challenges of growing the NPO and voluntary sector in Japan. In The Voluntary and Non-Profit Sector in Japan: The Challenge of Change, 1st ed.; Osborne, S.P., Ed.; Routledge: London, UK, 2003; pp. 121-149.

52. Nazarov, E. Emergency Response Management in Japan: Final Research Report, 1st ed.; Asian Disaster Reduction Center: Kobe, Japan, 2011; pp. 5-32.

53. Suzuki, I. Roles of volunteers in disaster prevention: Implications of questionnaire and interview surveys. In A Better Integrated Management of Disaster Risks: Toward Resilient Society to Emerging Disaster Risks in Mega-Cities, 1st ed.; Ikeda, S., Fukuzono, T., Sato, T., Eds.; TERRAPUB: Tokyo, Japan, 2006; pp. 153-163.

54. Cabinet Office. Available online: https://www.cao.go.jp/index-e.html (accessed on 21 January 2021).

55. Lee, A.-R. Social network model of political participation in Japan. Jpn. J. Political Sci. 2016, 17, 44-62. [CrossRef] 
56. Japan Women's Network for Disaster Risk Reduction. Available online: https://www.preventionweb.net/organizations/13363 (accessed on 3 December 2020).

57. Pharr, S. Conclusion: Targeting by an activist state: Japan as a civil society model. In The State of Civil Society in Japan, 1st ed.; Schwartz, F.J., Pharr, S.J., Eds.; Cambridge University Press: Cambridge, UK, 2003; pp. 316-336.

58. Leng, R. Japan's civil society from Kobe to Tohoku: Impact of policy changes on government-NGO relationship and effectiveness of post-disaster relief. Electron. J. Contemp. Jpn. Stud. 2015, 15, 1-23.

59. Japan's National Land Agency (JNLA). Disaster Countermeasures Basic Act, 1st ed.; JNLA: Tokyo, Japan, $1997 ;$ pp. 1-57.

60. ESCAP Annual Report 2014. Available online: https://www.unescap.org/sites/default/files/ESCAP-Annual-Report-2014.pdf (accessed on 16 December 2020).

61. Hong, S.; Khim, J.S.; Ryu, J.; Kang, S.-G.; Shim, W.J.; Yim, U.H. Environmental and ecological effects and recoveries after five years of the Hebei Spirit oil spill, Taean, Korea. Ocean Coast. Manag. 2014, 102, 522-532. [CrossRef]

62. Kim, S. Voluntary organizations as new street-level bureaucrats: Frontline struggles of community organizations against bureaucratization in a South-Korean welfare-to-work partnership. Soc. Policy Adm. 2013, 47, 565-585. [CrossRef]

63. Ministry of Foreign Affairs (MOFA). Available online: http://www.mofa.go.kr/www/index.do (accessed on 3 December 2020).

64. Korean Red Cross. Available online: https://www.redcross.or.kr/eng/eng_main/main.do (accessed on 3 October 2020).

65. Bae, Y.; Joo, Y.-M.; Won, S.-Y. Decentralization and collaborative disaster governance: Evidence from South Korea. Habitat Int. 2016, 52, 50-56. [CrossRef] [PubMed]

66. Ministry of the Interior and Safety (MOIS). Available online: https://www.mois.go.kr/frt/a01/frtMain.do (accessed on 22 January 2021).

67. Choi, S.O.; Yang, S.-B. Understanding challenges and opportunities in the nonprofit sector in Korea. Int. Rev. Public Adm. 2011, 16, 51-70. [CrossRef]

68. Laws and Policies Affecting Volunteerism Since 2001. Available online: https://www.unv.org/sites/default/files/Volunteerism\% 20laws\%20and\%20policies\%202009.pdf (accessed on 27 November 2020).

69. Rehnborg, S.J.; Bailey, W.L.; Moore, M.; Sinatra, C. Strategic Volunteer Engagement: A Guide for Nonprofit and Public Sector Leaders, 1st ed.; OneStar Foundation: Austin, TX, USA, 2009; pp. 89-111.

70. Richardson, M. Civil society and the state in South Korea. In SAIS U.S.-Korea Yearbook, 1st ed.; Noh, A., Ed.; K-Developedia (KDI School) Repository: Washington, DC, USA, 2010; pp. 165-176.

71. Mills, M.; van de Bunt, G.G.; de Bruijn, J. Comparative research: Persistent problems and promising solutions. Int. Sociol. 2006, 21, 619-631. [CrossRef]

72. Why You Need to Learn from Your Mistakes. Available online: http:/ / elitedaily.com/life/why-you-need-to-learn-from-yourmistakes / (accessed on 16 December 2020).

73. Nakayachi, K.; Ozaki, T. A method to improve trust in disaster risk managers: Voluntary action to share a common fate. Int. J. Disaster Risk Reduct. 2014, 10, 59-66. [CrossRef]

74. Hollis, S. The global standardization of regional disaster risk management. Camb. Rev. Int. Aff. 2014, 27, 319-338. [CrossRef]

75. Shaw, R.; Goda, K. From disaster to sustainable civil society: The Kobe experience. Disasters 2004, 28, 16-40. [CrossRef]

76. Carafano, J.J. The Great Eastern Japan Earthquake: Assessing Disaster Response and Lessons for the United States, 1st ed.; Heritage Foundation: Washington, DC, USA, 2011; pp. 2-7.

77. Palttala, P.; Boano, C.; Lund, R.; Vos, M. Communication gaps in disaster management: Perceptions by experts from governmental and non-governmental organizations. J. Contingencies Crisis Manag. 2012, 20, 2-12. [CrossRef]

78. Sharing Experiences with Others Makes Them More Intense: Carrying Out Tasks in a Group Amplifies How They Make You Feel. Available online: http:/ / www.dailymail.co.uk/sciencetech/article-2785035/Sharing-experiences-makes-INTENSE-Carryingtasks-group-amplifies-make-feel.html (accessed on 24 November 2020).

79. United Nations Volunteers (UNV). Assessing the Contribution of Volunteering to Development: A Participatory Methodology, 1st ed.; UNV: Bonn, Germany, 2011; pp. 18-47.

80. Whittaker, J.; McLennan, B.; Handmer, J. A review of informal volunteerism in emergencies and disasters: Definition, opportunities and challenges. Int. J. Disaster Risk Reduct. 2015, 13, 358-368. [CrossRef]

81. Habib, M.S.; Sakar, B.; Tayyab, M.; Saleem, M.W.; Hussain, A.; Ullah, M.; Omair, M.; Iqbal, M.W. Large-scale disaster waste management under uncertain environment. J. Clean. Prod. 2019, 212, 200-222. [CrossRef] 